LETTERS

\title{
Adverse events in patients with rheumatoid arthritis treated with infliximab in daily clinical practice
}

\author{
N Neven, M Vis, A E Voskuyl, G J Wolbink, M T Nurmohamed, B A C Dijkmans, W F Lems
}

Ann Rheum Dis 2005;64:645-646. doi: 10.1136/ard.2004.028597

linas nfliximab is highly effective and relatively safe for the reatment of patients with rheumatoid arthritis (RA) in clinical trials. ${ }^{1-5}$ This prospective cohort study was undertaken to determine adverse events, in particular, infections in patients with RA treated with infliximab in daily clinical practice.

\section{METHODS AND RESULTS}

We treated 168 patients with RA between 1 April 2000 and 1 October 2002, 82\% female, with a median disease duration of 10 years (range 1-49). Inclusion criteria were 28 joint count Disease Activity Score (DAS28) of $>3.5$ and failure of two disease modifying antirheumatic drugs, including methotrexate. Patients with heart failure or with a malignancy 5 years before screening were excluded. After the alert about tuberculosis, ${ }^{6}$ patients starting with infliximab treatment were screened for that disease.

All patients were treated with an initial infliximab dose of $3 \mathrm{mg} / \mathrm{kg}$ (weeks 0, 2, 6, and subsequently, every 8 weeks). When the response was insufficient-that is, a decrease in DAS28 < 1.2 compared with baseline on two subsequent occasions, the dose could be increased to $7.5 \mathrm{mg} / \mathrm{kg}$. The median duration of treatment was 0.86 years (range 0-2.5); the median number of infusions used was 7 (range 1-18). Methotrexate and prednisone were used by $92 \%$ and $50 \%$ of the patients, respectively.

Patients were systematically asked about events and, explicitly, about infections at each visit. All events occurring during the infliximab treatment period were interpreted as adverse events.

The most common mild adverse event was short lived headache. Early allergic reactions were seen in 12 patients (0.08/patient-year), but none developed severe cardiopulmonary problems. Some cases of heart failure $(n=2)$, neuropathy $(n=1)$, and malignancy $(n=2)$ were observed. Two patients died during the study, one of a cerebrovascular accident and one of unknown cause.
Patients frequently (43-57\%, depending on the definition used) had infections, most commonly from the upper respiratory tract and the lower urinary tract (table 1). One case of tuberculosis was seen. The number of clinically important infections was 0.59 /patient-year, whereas serious infections were found in 0.08/patient-year.

Compared with patients receiving low dose infliximab, significantly $(\mathrm{p}<0.05)$ more patients with the increased dose had clinically important infections (including serious infections), but other adverse events, demographic characteristics, and drug use between the groups were comparable. After correction for treatment duration with infliximab, the rate of clinical infections was significantly higher in the group receiving the increased dose. However, after correction for treatment duration, clinically important infections were not significantly more common in the group receiving the increased dose.

\section{DISCUSSION}

Our study has shown that infection is the most common adverse event of infliximab treatment in daily practice. Clinical infections and clinically important infections were found more frequently in patients receiving high dose infliximab, without proven causality.

The occurrence of infections in our study is in the same range as that described in (randomised) clinical trials of infliximab. ${ }^{1357}$ However, the incidence of infection in our study was much higher than those described in a population based study of patients with RA not treated with infliximab, 64 versus 32 events per patient per year. ${ }^{8}$

There is evidence that a higher risk for infections occurs with a higher RA activity. ${ }^{9}$ It is reasonable to suppose that patients with a dose increase had greater disease activity than those treated with only low dose infliximab. We are unable to comment on whether the higher incidence of infections is associated with a high disease activity or with the strong immunosuppressive action of infliximab, or both.

Table 1 Occurrence of adverse events in 168 patients with RA treated with infliximab

\begin{tabular}{|c|c|c|c|c|c|c|c|c|c|}
\hline \multirow[b]{2}{*}{ Adverse events } & \multirow[b]{2}{*}{ No $(\%)$} & \multirow[b]{2}{*}{ Events } & \multirow[b]{2}{*}{$\begin{array}{l}\text { Events/ } \\
\text { patient/year }\end{array}$} & \multicolumn{3}{|c|}{$3 \mathrm{mg} / \mathrm{kg}$ infliximab $(\mathrm{n}=132$ ) } & \multicolumn{3}{|c|}{$3 \rightarrow 7.5 \mathrm{mg} / \mathrm{kg}$ infliximab $(\mathrm{n}=36)$} \\
\hline & & & & No (\%) & Events & $\begin{array}{l}\text { Events/ } \\
\text { patient/year }\end{array}$ & No (\%) & Events & $\begin{array}{l}\text { Events/ } \\
\text { patient/year }\end{array}$ \\
\hline Any adverse event & $122(73)$ & 208 & 1.44 & $89(67)$ & 152 & 1.40 & $30(83)$ & 56 & 1.30 \\
\hline All infections* & $96(57)$ & 153 & 1.06 & $69(52)$ & 109 & 1.01 & $27(75)$ & 44 & 1.02 \\
\hline Clinical infections $\dagger$ & $72(43)$ & 93 & 0.64 & $50(38)$ & 65 & 0.41 & $22(61)$ & 28 & 0.65 \\
\hline Clinically important infections $\ddagger$ & $60(36)$ & 85 & 0.59 & $42(32)$ & 59 & 0.55 & $18(50)$ & 26 & 0.60 \\
\hline Antibiotics (po) & $50(30)$ & 74 & 0.51 & $35(27)$ & 51 & 0.47 & $15(42)$ & 23 & 0.53 \\
\hline Serious infections§ & $10(6)$ & 11 & 0.08 & $7(5)$ & 8 & 0.07 & $3(8)$ & 3 & 0.07 \\
\hline
\end{tabular}


In conclusion, infliximab can be used safely in daily clinical practice, but both doctors and patients should be aware of the (infection) risks, especially in patients receiving a higher dose $(>3 \mathrm{mg} / \mathrm{kg})$ of infliximab, in order to anticipate and minimise these risks.

\section{Authors' affiliations \\ N Neven, M Vis, G J Wolbink, W F Lems, Department of Rheumatology, Slotervaart Hospital, Amsterdam, The Netherlands \\ A E Voskuyl, B A C Dijkmans, Department of Rheumatology, VU University Medical Centre, Amsterdam, The Netherlands M T Nurmohamed, Department of Rheumatology, Jan van Breemen Institute, Amsterdam, The Netherlands}

Correspondence to: Dr A E Voskuyl, Department of Rheumatology 4A42, VU University Medical Centre, De Boelelaan 1117, 1081 HV Amsterdam, The Netherlands; ae.voskuyl@vumc.nl

Accepted 18 August 2004

\section{REFERENCES}

1 Maini R, St Clair EW, Breedveld F, Furst D, Kalden J, Weisman M, et al. Infliximab (chimeric anti-tumour necrosis factor alpha monoclonal antibody) versus placebo in rheumatoid arthritis patients receiving concomitant methotrexate: a randomised phase III trial. ATTRACT Study Group. Lancet 1999;354:1932-9.

2 Lipsky PE, van der Heijde DM, St Clair EW, Furst DE, Breedveld FC, Kalden JR, et al. Infliximab and methotrexate in the treatment of rheumatoid arthritis. Anti-Tumor Necrosis Factor Trial in Rheumatoid Arthritis with Concomitant Therapy Study Group. N Engl J Med 2000;343:1594-602.

3 Elliott MJ, Maini RN, Feldmann M, Kalden JR, Antoni C, Smolen JS, et al. Randomised double-blind comparison of chimeric monoclonal antibody to tumour necrosis factor alpha (cA2) versus placebo in rheumatoid arthritis. Lancet 1994;344:1105-10.

4 Harriman G, Harper LK, Schaible TF. Summary of clinical trials in rheumatoid arthritis using infliximab, an anti-TNFalpha treatment. Ann Rheum Dis 1999;58(Suppl I):i61-4.

5 Kroesen S, Widmer AF, Tyndall A, Hasler P. Serious bacterial infections in patients with rheumatoid arthritis under anti-TNF-alpha therapy. Rheumatology (Oxford) 2003;42:617-21.

6 Keane J, Gershon S, Wise RP, Mirabile-Levens E, Kasznica J, Schwieterman WD, et al. Tuberculosis associated with infliximab, a tumor necrosis factor alpha-neutralizing agent. N Engl J Med 2001;345:1098-104.

7 Fitzcharles MA, Clayton D, Menard HA. The use of infliximab in academic rheumatology practice: an audit of early clinical experience. J Rheumatol 2002;29:2525-30.

8 Doran MF, Crowson CS, Pond GR, O'Fallon WM, Gabriel SE. Frequency of infection in patients with rheumatoid arthritis compared with controls: a population-based study. Arthritis Rheum 2002;46:2287-93.

9 Doran MF, Crowson CS, Pond GR, O'Fallon WM, Gabriel SE. Predictors of infection in rheumatoid arthritis. Arthritis Rheum 2002;46:2294-300.

\title{
Fever and increasing CANCA titre after kidney and autologous stem cell transplantation for Wegener's granulomatosis
}

\author{
T Daikeler, C Erley, M Mohren, C Amberger, H Einsele, L Kanz, I Kötter
}

Ann Rheum Dis 2005;64:646-647. doi: 10.1136/ard.2004.029009

W egener's granulomatosis is a systemic vasculitis mainly affecting the lungs, nasal sinuses, and kidneys. Treatment usually consists of cyclophosphamide (Cy) and steroids. ${ }^{1}$ High dose Cy with autologous stem cell support could be an alternative treatment for patients resistant to conventional treatment or requiring long term immunosuppression with the risk of secondary malignancy. ${ }^{2}$

\section{CASE REPORT}

We report on a 33 year old woman with chronic relapsing sinusitis, pulmonary granuloma, and proteinuria with progressive renal insufficiency since 1988. Renal biopsy showed necrotising glomerulonephritis, and biopsy of the nasal sinus showed granuloma with necrotising vasculitis. Proteinase-3antineutrophil cytoplasmic antibodies (PR3-ANCA) were detectable with a titre of $1 / 280$. Despite treatment with Cy $\left(750 \mathrm{mg} / \mathrm{m}^{2}\right.$ every 3 weeks, later $100 \mathrm{mg} /$ day orally) and steroids renal function deteriorated, and she underwent dialysis from April 1995 to December 1998. Live kidney transplantation from the patient's sister matched for HLA was performed in December 1998. Irrespective of ciclosporin A (CSA), which was given as prophylaxis for host versus graft reaction, she continuously needed immunosuppression with Cy (orally, $100 \mathrm{mg} /$ day) because of persistent disease activity with relapsing pulmonary infiltrations. The transplanted kidney remained unaffected.
A cumulative Cy dose of over $100 \mathrm{~g}$ was reached and in view of the relapsing pulmonary granuloma and increasing PR3-ANCA titres, which in our patient correlated well with disease activity, stem cell mobilisation was performed in May 1999 with Cy $4 \mathrm{~g} / \mathrm{m}^{2}$ followed by granulocyte-colony stimulating factor $5 \mu \mathrm{g} / \mathrm{kg}$ for 10 days. Stem cell apheresis and selection of CD34+ stem cells was performed using the CliniMacs device on day 10. When PR3-ANCA titres increased from $1 / 128$ to $1 / 500$ after 4 months, high dose immunosuppression with Cy $50 \mathrm{mg} / \mathrm{kg}$ days $\mathrm{l}-4$ and ATG $5 \mathrm{mg} / \mathrm{kg}$ days $1-4$, followed by retransfusion of $2.82 \times 10^{6} \mathrm{CD} 34+$ cells $/ \mathrm{kg}$ body weight was given. The conditioning regimen was chosen according to the protocol for aplastic anaemia. ${ }^{3}$ Marked clinical improvement was seen with a regression of pulmonary infiltrates on chest $x$ ray examination. Complete haematological reconstitution was achieved on day 12 after stem cell retransfusion. CSA was continued for renal graft protection.

Five months after high dose Cy, the patient was admitted with malaise, high grade fever, and pancytopenia. The PR3ANCA titre was $1 / 1000$, but computed tomography scans of the lungs and nasal sinuses were normal. An active EpsteinBarr virus (EBV) infection was diagnosed by serology (IgG and IgM). Polymerase chain reaction disclosed a high plasmatic viral load with 1270000 EBV transcripts per 100 ng genomic DNA. Treatment with intravenous ganciclovir and immunoglobulins led to resolution of all symptoms. 


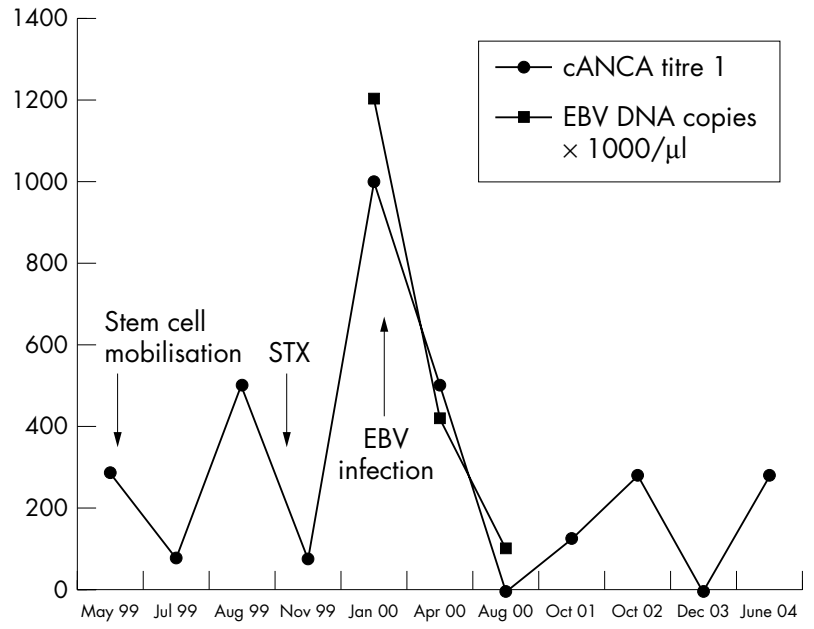

Figure 1 PR3-ANCA titre and the number of EBV DNA copies before stem cell mobilisation May 1999, before stem cell transplantation (STX) September 1999, and during EBV infection.

The PR3-ANCA titre fell in parallel with the EBV viral load in plasma (fig 1).

The patient remains in remission of Wegener's granulomatosis now 5 years after transplantation continuing treatment with low dose CSA ( $3 \mathrm{mg} / \mathrm{kg}$ body weight) and, later, mycophenolate mofetil $(2 \times 1 \mathrm{~g})$ for host versus graft reaction prophylaxis. The CD3+, CD4+ T helper cells are still slightly lowered at $664 \times 10^{6}$ cells/ 1 and the $C D 4 / C D 8$ ratio is reduced to 0.63 . PR3-ANCA titres vary between 0 and $1 / 280$, but have not consistently been negative (fig l).

\section{DISCUSSION}

High dose immunosuppression with in vitro and in vivo T cell purging followed by autologous stem cell support was effective in our patient with severe, refractory Wegener's granulomatosis. It remains to be seen if disease remission continues after complete immune reconstitution. To our knowledge, this is the first reported case of refractory Wegener's granulomatosis successfully treated with high dose immunosuppression and autologous stem cell support. Five cases (including this one) are registered in the European Group for Blood and Bone Marrow Transplantation database. Intensive $\mathrm{T}$ cell depletion bears an increased risk of opportunistic infections as seen in our patient with an unusual course of an EBV infection. The increase of the PR3ANCA titre during EBV infection fits the hypothesis that Wegener's granulomatosis may be triggered by infectious agents $^{4}$ and is supported by the findings of Mayet et al, ${ }^{5}$ who found cANCA production after transforming B cells in vitro with EBV.

\section{Authors' affiliations}

T Daikeler, C Amberger, H Einsele, L Kanz, I Kötter, Department of Rheumatology, Haematology, Immunology and Oncology, University Hospital Tübingen, Germany

C Erley, Department of Nephrology, University Hospital Tübingen, Germany

M Mohren, Department of Haematology, University Hospital Magdeburg, Germany

The first and last authors contributed equally to this work.

Correspondence to: Dr I Kötter, Department of Internal Medicine II, University Hospital, Otfried-Müller-Str 10, D-72076 Tübingen,

Germany; ina.koetter@med.uni-tuebingen.de

Accepted 18 September 2004

\section{REFERENCES}

1 Hoffman GS, Gross WL, Wegener's granulomatosis: clinical aspects. In: Inflammatory diseases of the blood vessels, In: Hoffman GS, Weyand CM, eds. New York/Basel: Marcel Dekker Inc, 2002:381-97.

2 Tyndall A, Passweg J, Gratwohl A. Haemopoietic stem cell transplantation in the treatment of severe autoimmune diseases 2000. Ann Rheum Dis 2001:60:702-7.

3 Brodsky RA, Sensenbrenner LL, Smith BD, Dorr D, Seaman PJ, Lee SM, et al. Durable treatment-free remission after high-dose cyclophosphamide therapy for previously untreated severe aplastic anemia. Ann Intern Med $2001 ; 135: 477-83$

4 Boudewyns A, Verbelen J, Koelkelkoren E, Van Offel J, Van de Heyning P. Wegener's granulomatosis triggered by infection? Acta Otorhinolaryngol Belg 2001; 55:57-63.

5 Mayet WJ, Hermann E, Kiefer B, Lehmann H, Manns M, Meyer zum Buschenfelde $\mathrm{KH}$. In vitro production of anti-neutrophilocyte-cytoplasmantibodies (ANCA) by Epstein-Barr virus transformed B-cell lines in Wegener's granulomatosis. Autoimmunity 1991;11:13-19.

\section{Refractory adult onset Still's disease successfully treated with anakinra}

F M Vasques Godinho, M J Parreira Santos, J Canas da Silva

$\mathrm{P}$ roinflammatory cytokines like tumour necrosis factor $\alpha$ (TNF $\alpha$ ), interleukin (IL) 6, IL18, and ILl have been implicated in the pathogenesis of several chronic rheumatic inflammatory diseases, including juvenile idiopathic arthritis and adult onset Still's disease (AOSD). ${ }^{1-5}$ The treatment of these diseases includes non-steroidal antiinflammatory drugs (NSAIDs), systemic corticosteroids and, in resistant cases, methotrexate (MTX), cyclophosphamide, sulfasalazine, and ciclosporin $\mathrm{A}^{6-8}$ have been used. Over the past years, several cases of successful treatment with infliximab and etanercept in AOSD, refractory to conventional drugs, have been published. ${ }^{8}$,

\section{CASE REPORT}

We report a favourable response to anakinra in a patient unresponsive to several disease modifying antirheumatic drugs (DMARDs) and TNF $\alpha$ blockers, requiring chronic high doses of steroids. The patient is a 32 year old woman diagnosed at the age 18 with AOSD, defined by the criteria of Yamaguchi et al. ${ }^{10}$ She was treated with NSAIDs, systemic 
Table 1 Clinical evolution of the patient

\begin{tabular}{|c|c|c|c|c|c|c|c|}
\hline & \multirow[b]{2}{*}{ Jun 2000} & \multicolumn{2}{|l|}{ Infliximab } & \multicolumn{2}{|l|}{ Etanercept } & \multicolumn{2}{|l|}{ Anakinra } \\
\hline & & Oct 2000 & Jun 2001 & Aug 2001 & Sept 2002 & Oct 2002 & Mar 2004 \\
\hline $\begin{array}{l}\text { Haemoglobin }(\mathrm{mg} / \mathrm{l}) \\
\text { Leucocytes }\left(\times 10^{9} / \mathrm{l}\right) \\
\text { ESR }(\mathrm{mm} / 1 \mathrm{st} \mathrm{h}) \\
\text { Platelets }\left(\times 10^{9} / \mathrm{l}\right) \\
\text { Fever } \\
\text { Arthritis } \\
\text { Arthralgias } \\
\text { PDN doses (mg/day) }\end{array}$ & $\begin{array}{l}89 \\
18.3 \\
112 \\
591 \\
\text { Yes } \\
\text { Yes } \\
\text { Yes } \\
40\end{array}$ & $\begin{array}{l}88 \\
26.3 \\
120 \\
777 \\
\text { Yes } \\
\text { Yes } \\
\text { Yes } \\
30\end{array}$ & $\begin{array}{l}94 \\
26.0 \\
117 \\
703 \\
\text { Yes } \\
\text { Yes } \\
\text { Yes } \\
30\end{array}$ & $\begin{array}{l}87 \\
17.1 \\
120 \\
689 \\
\text { Yes } \\
\text { Yes } \\
\text { Yes } \\
15\end{array}$ & $\begin{array}{l}92 \\
23.6 \\
107 \\
748 \\
\text { Yes } \\
\text { Yes } \\
\text { Yes } \\
20\end{array}$ & $\begin{array}{l}92 \\
23.6 \\
112 \\
748 \\
\text { Yes } \\
\text { Yes } \\
\text { Yes } \\
20\end{array}$ & $\begin{array}{l}12.4 \\
8.1 \\
13 \\
387 \\
\text { No } \\
\text { No } \\
\text { No } \\
0\end{array}$ \\
\hline
\end{tabular}

steroids, and several DMARDs (MTX, sulfasalazine, and ciclosporin A) over a period of 10 years, but she had sustained disease with frequent flares requiring high doses of steroids (up to $1 \mathrm{mg} / \mathrm{kg} /$ day).

At the age of 28 , she was referred to our rheumatology unit with persistent fever, arthritis, anaemia, leucocytosis, and raised serum level of $\mathrm{C}$ reactive protein, erythrocyte sedimentation rate (ESR), and ferritin despite treatment with prednisolone $30 \mathrm{mg} /$ day, naproxen $1 \mathrm{~g} /$ day, and MTX $20 \mathrm{mg} /$ week. At examination she had six tender and six swollen joints and reduced range of motion of the neck, wrists, and hips. Screening tests for infection were negative. She was treated with intravenous immunoglobulin $(2 \mathrm{~g} / \mathrm{kg})$ and prednisolone, and MTX was increased up to $25 \mathrm{mg} /$ week subcutaneously (SC), but only showed a partial response. At 2 months' follow up the patient reported difficulty in walking, with increased hip pain. A pelvic $x$ ray examination disclosed bilateral aseptic necrosis of the femoral heads and she was admitted for total bilateral hip arthroplasty.

In October 2000 infliximab was added to her treatment, initially at a dose of $3 \mathrm{mg} / \mathrm{kg}$ and increased to $5 \mathrm{mg} / \mathrm{kg}$. Six months later she continued to have fever, arthritis (19 tender and two swollen joints) and a raised ESR (117 mm/lst h); infliximab was discontinued. Treatment was changed to etanercept, 25 mg SC, twice a week for 54 weeks, with little clinical response. Throughout this period she continued to have intermittent fever, arthritis, and raised serological inflammatory markers.

In October 2002 it was decided to attempt anakinra $100 \mathrm{mg} /$ day SC in addition to MTX $25 \mathrm{mg} /$ week SC, prednisolone $20 \mathrm{mg} /$ day, and naproxen. An impressive improvement of the systemic features and joint disease occurred over the first weeks of treatment and the acute phase reactants returned to normal. Steroids could be reduced and discontinued. Anakinra was well tolerated and no adverse effects were seen. After 18 months of follow up the patient remains in full clinical remission, without steroids or NSAIDs (table 1 ).

This is, to our knowledge, the first reported case of successful treatment of AOSD with anakinra.

\section{DISCUSSION}

Although TNF $\alpha$ antagonists have revolutionised the treatment of refractory AOSD, some patients do not respond to this treatment. The dramatic response to anakinra in this case of AOSD refractory to conventional treatments and to anti-TNF $\alpha$ blockers, suggests that the inhibition of ILl may be an important therapeutic target in some patients.

\section{Authors' affiliations}

F M V Godinho, M J P Santos, J C da Silva, Rheumatology Department, Hospital Garcia de Orta, Almada, Portugal

Correspondence to: Dr F M Vasques Godinho, Av Prof Torrado da Silva, Hospital Garcia de Orta, Almada, Portugal; fatima_godinho@ hotmail.com

Accepted 12 August 2004

Published Online First 16 September 2004

\section{REFERENCES}

1 Fujii T, Nojima T, Yasuoka S, Satoh S, Nakamura K, Kuwana M, et al. Cytokine and immunogenetic profiles in Japanese patients with adult Still's disease. Association with chronic articular disease. Rheumatology (Oxford) 2001;40:1398-404

2 Vencovský J, Jarošová K, Ružičková S, Nemcova D, Niederlova J, Ozen S, et al. Higher frequency of allele 2 of the interleukin-1 receptor antagonist gene in patients with juvenile idiopathic arthritis. Arthritis Rheum 2001;44:2387-91.

3 Müller K, Herner E, Stagg A, Bendtzen K, Woo P. Inflammatory cytokines and cytokine antagonists in whole blood cultures of patients with systemic juvenile chronic arthritis. Br J Rheumatol 1998; 37:562-9.

4 Elliott M, Woo P, Charles P, Long-Fox A, Woody JN, Maini RN. Suppression of fever and the acute-phase response in a patient with juvenile chronic arthritis treated with monoclonal antibody to tumour necrosis factor- $\alpha$ (cA2) $\mathrm{Br} J$ Rheumatol 1997;36:589-93.

5 Wilkinson N, Jackson G, Gardner-Medwin J. Biologic therapies for juvenile arthritis. Arch Dis Child 2003;88:186-91.

6 Marchesoni A, Ceravolo GP, Battafarano N, Rossetti A, Tosi S, Fantini F. Cyclosporin $A$ in the treatment of adult Still's disease. J Rheumatol 1997;24:1582-7.

7 Fujii T, Akizuki M, Kameda H, Matsumura M, Hirakata M, Yoshida T, et al. Methotrexate treatment in patients with adult Still's disease: retrospective study of 13 Japanese cases. Ann Rheum Dis 1997;56:144-8.

8 Husni M, Maier A, Mease P, Overman SS, Fraser P, Gravallese EM, et al. Etanercept in the treatment of adult patients with Still's disease. Arthritis Rheum 2002;46:1171-6.

9 Kokkinos A, lliopoulos A, Greka P, Efthymiou A, Katsilambros N, Sfikakis PP. Successful treatment of refractory adult-onset Still's disease with Infliximab. A prospective, non-comparative series of four patients. Clin Rheumatol 2004;23:45-9.

10 Yamaguchi M, Ohta A, Tsunematsu T, Kasukawa R, Mizushima Y Kashiwagi $\mathrm{H}$, et al. Preliminary criteria for classification of adult Still's disease. J Rheumatol 1992; 19:424-30. 


\title{
Neuropathy associated with leflunomide: a case series
}

\author{
K Martin, F Bentaberry, C Dumoulin, M Longy-Boursier, F Lifermann, F Haramburu, J Dehais, \\ T Schaeverbeke, B Bégaud, N Moore
}

eflunomide is a new disease modifying drug (DMARD) recently licensed for treatment of rheumatoid arthritis. This isoxazole derivative is a prodrug for the active metabolite A77 1726, which has immunosuppressive properties. Leflunomide is now part of the therapeutic arsenal presently available for rheumatic disease, and its safety profile has been assessed by clinical trials ${ }^{1-3}$ and extended clinical trials. ${ }^{4-7}$ Among adverse peripheral nervous events, only paraesthesia has been reported. Nevertheless, 14 cases of peripheral neuropathy occurring during leflunomide treatment for rheumatoid arthritis have been reported to the regional pharmacovigilance centre in Bordeaux (table 1).

The cases include seven men and seven women. Mean age at the start of treatment with leflunomide was 69 years (range 57-78). Median duration of treatment at the onset of neuropathy was 7.5 months (range 3 weeks -29 months). Median duration of disease at treatment onset was 8.2 years (range 1-20). All patients had previously received a $100 \mathrm{mg}$ loading dose of leflunomide for 3 days and were treated with a $20 \mathrm{mg}$ daily dose. All patients presented with paraesthesia. A nerve conduction study demonstrated either motor or sensory axonal neuropathy in four cases and sensory axonal neuropathy in 10 cases.

All the patients were concomitantly receiving several drugs. Four patients were diabetic. In two cases, retinal angiography did not disclose any diabetic macroangiopathy. In two patients (Nos 5 and 10), aspecific vasculitis was diagnosed by neuromuscular biopsy when the neuropathy was explored. No biopsy was performed for the others patient. In three patients (Nos 1, 5, and 12) the pANCA were positive. None of these cases were treated concomitantly with other neurotoxic DMARDs. One patient (No 12) was concomitantly treated with infliximab. Two patients (Nos 6 and 10) concomitantly received a statin for a long period. Another patient (No 6) was treated concomitantly with almitrine, a known neurotoxic drug. Nevertheless, the neuropathy did not resolve after almitrine was discontinued but improved after leflunomide was stopped. The condition of patient No 12, whose neuropathy was related to previous use of thalidomide, worsened as soon as leflunomide was prescribed. In two patients (Nos 5 and 8 ) a previous diagnosis of neuropathy was present. Nevertheless, the peripheral nervous system event also worsened as soon as the DMARD was started, with a much shorter delay of onset than in the other cases. Other possible causes of neuropathy (metabolic or immune disorders, vitamin deficiency, neoplasia, viral and bacterial serology, etc) were ruled out in all cases. In half of the patients, the neuropathy improved after 3-6 months when leflunomide was discontinued (no nerve conduction study was performed). In the other patients, the neuropathy did not worsen.

Although paraesthesia is mentioned in the drug's summary of product characteristics, we report here the first (as far as we know) case series of adverse peripheral nerve effects during leflunomide treatment. Although these neuropathies may be multifactorial, the individual cases (delay of onset of the neuropathy and improvement after the DMARD was stopped) seem to suggest that this drug may be neurotoxic.
Ann Rheum Dis 2005;64:649-650. doi: 10.1136/ard.2004.027193

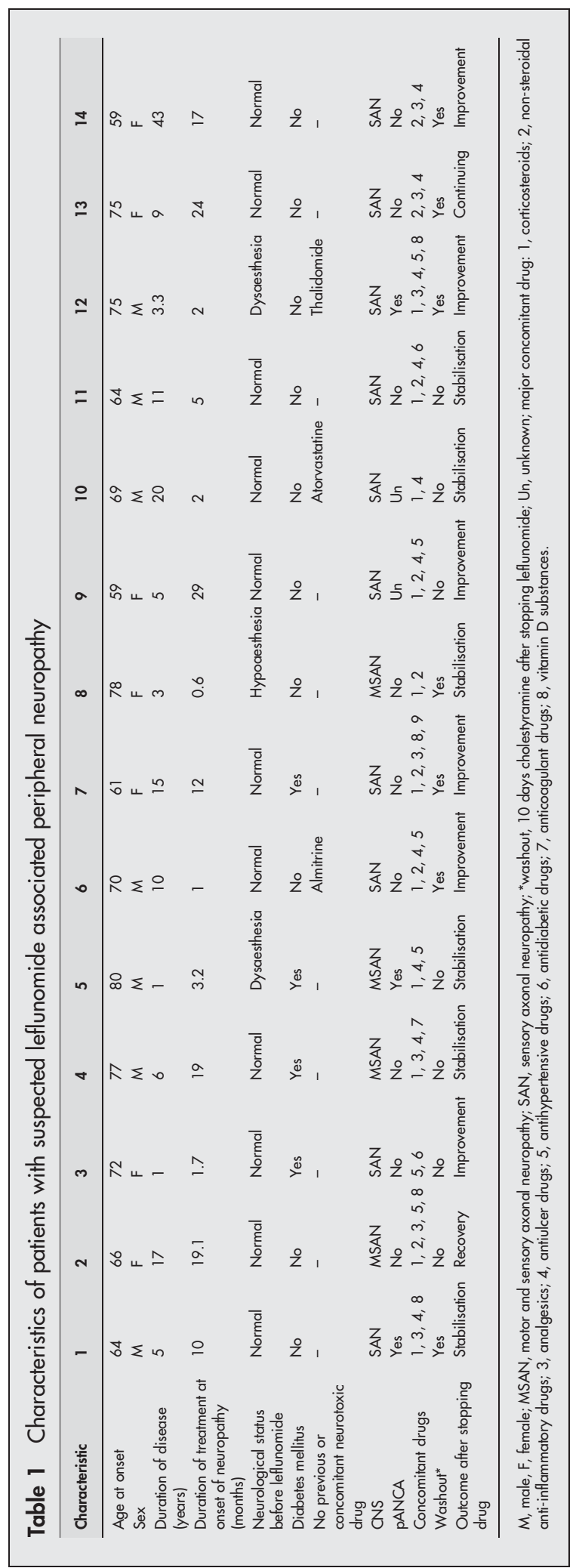


A report of only one other case has been published previously. ${ }^{8}$ To date, five other cases have been reported to the French pharmacovigilance system ${ }^{9}$ over a period of 2 years.

Carulli and Davies suggested that the neuropathy might be due to a neurological vasculitis induced by leflunomide. ${ }^{8}$ In the absence of a neuromuscular biopsy, this hypothesis could not be confirmed, but it is supported by a case report of cutaneous vasculitis induced by leflunomide without any neurological disorder. ${ }^{10}$ Moreover, two cases in this case series presented with aspecific vasculitis diagnosed by neuromuscular biopsy when the aetiology of the neuropathy was explored.

Clearly, clinicians should be aware of the possibility of peripheral neuropathy in patients treated with leflunomide, especially when other risk factors are present. This does not detract from the usefulness of this drug in the treatment of rheumatoid arthritis.

\section{Authors' affiliations}

K Martin, F Haramburu, Inserm U 657, Bordeaux, France; Centre Régional de Pharmacovigilance, Département de Pharmacologie, $\mathrm{CHU}$ de Bordeaux, 33076 Bordeaux, France

F Bentaberry, C Dumoulin, J Dehais, T Schaeverbeke, Service de Rhumatologie, $\mathrm{CHU}$, Bordeaux, France

M Longy-Boursier, Service de Médecine Interne, CHU, Bordeaux, France

F Lifermann, Service de Médecine Interne, CHG Dax, France K Martin, F Haramburu, B Bégaud, N Moore, Inserm U 657, Bordeaux, France; Département de Pharmacologie, IFR99, Université Victor Segalen, 33076 Bordeaux, France

Correspondence to: Dr K Martin, Inserm U 657, IFR 99; MP2S, Département de Pharmacologie, Zone Nord, Bâtiment 1A, Université
Victor Segalen - CHU, 33076 Bordeaux cedex, France; karin.martin@ pharmaco.u-bordeaux 2 .fr

Accepted 18 September 2004

\section{REFERENCES}

1 Strand V, Cohen S, Schiff M, Weaver A, Fleischmann R, Cannon G, et al. Treatment of active rheumatoid arthritis with leflunomide compared with placebo and methotrexate. Arch Intern Med 1999;159:2542-50.

2 Emery P, Breedveld FC, Lemmel EM, Kaltwasser JP, Dawes PT, Gömör B, et al. A comparison of the efficacy and safety of leflunomide and methotrexate for the treatment of rheumatoid arthritis. Rheumatology 2000;39:655-65.

3 Smolen JS, Kalden JR, Scott DL, Rozman B, Kvien TK, Larsen A, et al. Efficacy and safety of leflunomide compared with placebo and sulphasalazine in active rheumatoid arthritis: a double-blind, randomised, multicentre trial. Lancet 1999;353:259-66.

4 Kalden JR, Scott DL, Smolen JS, Schattenkirchner M, Rozman B, Williams BD, et al. European Leflunomide Study Group. Improved functional ability in patients with rheumatoid arthritis-longterm treatment with leflunomide versus sulfasalazine. European Leflunomide Study Group. J Rheumatol 2001;28:1983-91.

5 Cohen S, Cannon GW, Schiff M, Weaver A, Fox R, Olsen N, et al. Two-year, blinded, randomized, controlled trial of treatment of active rheumatoid arthritis with leflunomide compared with methotrexate. Utilization of Leflunomide in the Treatment of Rheumatoid Arthritis Trial Investigator Group. Arthritis Rheum 2001;44:1984-92.

6 Scott DL, Smolen JS, Kalden JR, van de Putte LB, Larsen A, Kvien TK, et al. Treatment of active rheumatoid arthritis with leflunomide: two year follow up of a double blind, placebo controlled trial versus sulfasalazine. Ann Rheum Dis $2001 ; 60: 913-23$

7 Kalden JR, Schattenkirchner M, Sorensen H, Emery P, Deighton C, Rozman B, et al. The efficacy and safety of leflunomide in patients with active rheumatoid arthritis: a five-year followup study. Arthritis Rheum 2003;48:1513-20.

8 Carulli MT, Davies UM. Peripheral neuropathy: an unwanted effect of leflunomide? Rheumatology 2002;41:952-3.

9 Moore N, Biour M, Paux G, Loupi E, Begaud B, Boismare F, et al. Adverse drug reaction monitoring: doing it the French way. Lancet 1985;2:1056-8.

10 Holm EA, Balslev E, Jemec GB. Vasculitis occurring during leflunomide therapy. Dermatology 2001;203:258-9.

\section{Tumour necrosis factor $\alpha$ antagonists and early postoperative complications in patients with inflammatory joint disease undergoing elective orthopaedic surgery}

\section{S C Talwalkar, D M Grennan, J Gray, P Johnson, M J Hayłon}

T umour necrosis factor $\alpha(\mathrm{TNF} \alpha)$ antagonists are now established as therapeutic agents for active rheumatoid arthritis (RA) resistant to conventional drug treatment. ${ }^{1}$ However, they decrease resistance to infection, including unusual infections such as tuberculosis, ${ }^{2}{ }^{3}$ and in an experimental setting have been shown to impair wound healing. ${ }^{4}$ Previous studies have shown that TNF $\alpha$ antagonists do not increase the risk of postoperative surgical complications in patients with Crohn's disease who undergo resective bowel surgery, ${ }^{56}$ but the safety of these drugs in patients with RA who undergo elective orthopaedic surgery has not yet been established.

As over $10 \%$ of patients with RA at our institution receiving antirheumatic drugs still require some form of elective orthopaedic surgical intervention we carried out a retrospective study of patients who received anti-TNF drug treatment before elective orthopaedic surgery.

Depending on the complexity, operations were divided into major surgery, including joint replacement surgery and lower limb arthrodeses; minor cases, including day case surgery;

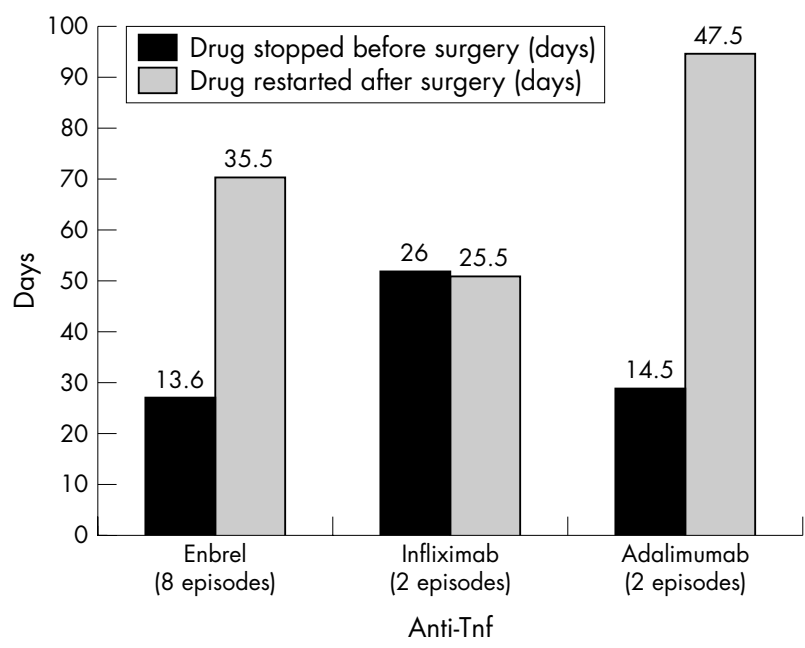

Figure 1 Time at which drug treatment was stopped and restarted. 


\begin{tabular}{|c|c|c|c|}
\hline \multirow[b]{2}{*}{ Group } & \multicolumn{2}{|c|}{ Complications } & \multirow[b]{2}{*}{ Type of surgery } \\
\hline & (n) & Type & \\
\hline$A(n=4)$ & 2 & $\begin{array}{l}\text { Reflex sympathetic dystrophy } \\
\text { Medial malleolar fracture }\end{array}$ & $\begin{array}{l}\text { Major (wrist replacement) } \\
\text { Major (total ankle replacement) }\end{array}$ \\
\hline$B(n=12)$ & 1 & Hip dislocation & Major (total hip replacement) \\
\hline
\end{tabular}

and the remaining procedures, which were in an intermediate group.

Patient records were used to identify which anti-TNF $\alpha$ antagonist was used. We reviewed 16 operations in 11 patients who had received an anti-TNF $\alpha$ drug in the perioperative period. Patients comprised six women and five men with a mean age of 57.8 years (range 33-75). Of the patients studied, 10 had RA and one patient had psoriatic arthritis. The average disease duration from diagnosis was 17.6 years (range 6-27).

Two groups of patients were identified. Group A represented patients in whom anti-TNF $\alpha$ drug treatment was continued in the postoperative period, whereas group B comprised patients for whom the drug was stopped before surgery and restarted after the procedure. In group A, infliximab was used in one operation, the patient receiving the injection 3 days before surgery while etanercept (Enbrel) was used in three patients. All the patients in group A underwent joint replacement surgery. Figure 1 shows when the different drugs were stopped and started with reference to surgery in group B. Infliximab, owing to its long half life and different administration schedule, was stopped nearly 4 weeks before surgery, whereas adalimumab and etanercept were stopped at 2 weeks. The timings for restarting the drug were variable and depended on the preference of individual consultants.

Three patients had complications (tablel). The patient who underwent hip replacement surgery required revision surgery to correct the femoral stem and had an inpatient stay of 55 days. In the remaining patients who underwent major surgery the duration of stay was between 6 and 13 days, with an average of 10.6 days.

There was no serious wound or systemic infections in any of the patients on follow up. Postoperatively, one flare up occurred in a patient receiving etanercept in group B, who underwent a triple arthrodesis of the ankle. The flare up developed during the postoperative period and was well controlled once the drug was restarted.

In a previous similar study by the authors, the overall rate of complications and infections in the perioperative period was found to be $10 \%$ in 388 patients. ${ }^{7}$ In the present study none of the patients being treated with an anti-TNF antagonist developed infections. Although two of the three complications were in group A, these were not thought to be to be drug related. Therefore in this small study there is no evidence that anti-TNF drug treatment, whether discontinued or continued, increased either the rate of infection or the complication rate.

\section{Authors' affiliations}

S C Talwalkar, M J Hayton, Department of Upper Limb Surgery, Wrightington Hospital, Manchester, UK

D M Grennan, Department of Rheumatology, Wrightington Hospital, Manchester, UK

J Gray, P Johnson, Clinical Trials Unit, Wrightington Hospital,

Manchester, UK

Correspondence to: Mr S C Talwalkar, 508 Imperial Point, The Quays, Manchester M50 3RA UK; stalwalkar@aol.com

Accepted 18 September 2004

\section{REFERENCES}

1 Rosandich PA, Kelley JT 3rd, Conn DL. Perioperative management of patients with rheumatoid arthritis in the era of biologic response modifiers. Curr Opin Rheumatol 2004; 16:192-8.

2 Keane J, Gershon S, Wise RP, Mirabile-Levens E, Kasznica J, Schwieterman WD, et al. Tuberculosis associated with infliximab, a tumor necrosis factor alpha-neutralizing agent. N Engl J Med 2001;345:1098-104.

3 Mohan AK, Cote TR, Block JA, Manadan AM, Siegel JN, Braun MM. Tuberculosis following the use of etanercept, a tumor necrosis factor inhibitor. Clin Infect Dis 2004;39:295-9. Epub 16 July 2004.

4 Mooney DP, O'Reilly M, Gamelli RL. Tumor necrosis factor and wound healing. Ann Surg 1990;211:124-9.

5 Marchal L, D'Haens G, Van Assche G, Vermeire S, Noman M, Ferrante M, et al. The risk of post-operative complications associated with infliximab therapy for Crohn's disease: a controlled cohort study. Aliment Pharmacol Ther 2004; 19:749-54.

6 Colombel JF, Loftus EV Jr, Tremaine WJ, Pemberton JH, Wolff BG, YoungFadok $T$, et al. Early postoperative complications are not increased in patients with Crohn's disease treated perioperatively with infliximab or immunosuppressive therapy. Am J Gastroenterol 2004;99:878-83.

7 Grennan DM, Gray J, Loudon J, Fear S. Methotrexate and early postoperative complications in patients with rheumatoid arthritis undergoing elective orthopaedic surgery. Ann Rheum Dis 2001;60:214-17.

\section{Cutaneous vasculitis developed in a patient with breast cancer undergoing aromatase inhibitor treatment}

\section{H Shoda, S Inokuma, N Yajima, Y Tanaka, K Setoguchi}




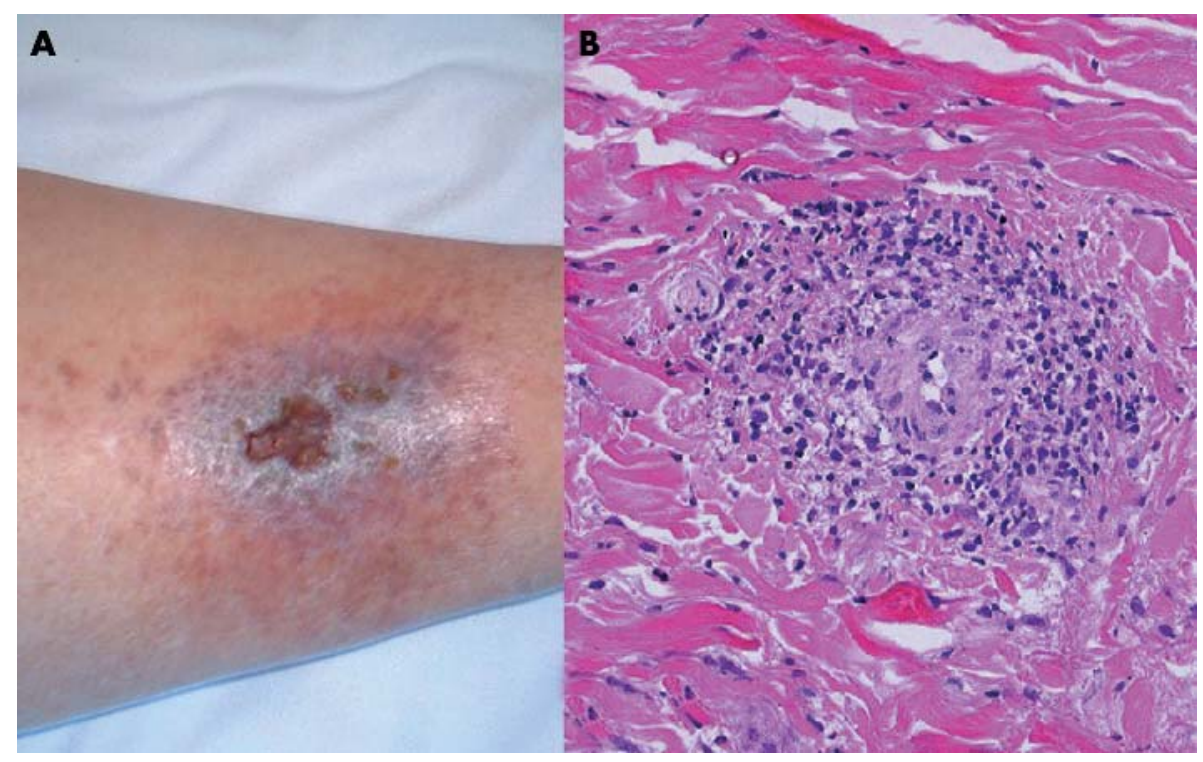

Figure 1 (A) A purpuric lesion and ulceration on the right leg. (B) Skin biopsy specimen of the purpuric lesion. Perivascular infiltration of inflammatory cells was seen. Haematoxylin and eosin, $\times 400$.

that developed during a therapeutic course of anastrozole for her breast cancer, in whom anastrozole was suspected to have had a role in inducing the vasculitis.

\section{CASE REPORT}

A 78 year old Japanese woman noticed a nodule in her left breast in November 2002. She had been taking a hydrogen blocker and antihypertensive drugs for many years. Breast cancer was cytologically diagnosed by aspiration biopsy, and her left breast was totally resected by the Auchincloss procedure in January 2003. No metastatic lesions were seen. The tumour cells were shown to be oestrogen receptor positive, and $1 \mathrm{mg}$ of anastrozole daily was prescribed immediately after the operation.

She noticed a small patch of slightly oedematous itchy purpura in both her pretibial areas in April 2003. After scratching the purpura, an ulceration developed on her right leg in July 2003. Fibroblast growth factor spray was ineffective, and the ulceration increased to a diameter of $2 \mathrm{~cm}$, with severe leg oedema; the purpuric lesion also progressed (fig 1A). A biopsy specimen obtained from her left pretibial purpuric lesion in September 2003 disclosed the infiltration of inflammatory cells, including lymphocytes and plasma cells, and karyorrhexis around small blood vessels in the dermis. Fluorescent antibody staining demonstrated IgA, IgM, and complements at the basement membrane of small blood vessels. No necrotising lesions were found (fig 1B).

After anastrozole treatment was stopped, purpuric papules, ulceration, and oedema all disappeared within 2 weeks without any additional treatment. The involvement of other organs, such as peripheral nerves, kidneys, and lungs, was not seen. Antinuclear antibody, antineutrophil cytoplasmic antibody, rheumatoid factor, and cryoglobulin were not detected. Sicca syndrome was ruled out owing to normal salivary and lachrymal secretions.

\section{DISCUSSION}

As far as we know, this is the first report that aromatase inhibitors may induce vasculitis. There have been some reports that hormonal drugs induce vasculitis. Tamoxifen, an oestrogen receptor antagonist, was reported to be a possible cause of cutaneous purpuric vasculitis. ${ }^{2}$ This past report suggested that inhibition of the oestrogen effect, which is the prevention of the pathogenesis of vasculitis, may in fact induce vasculitis. A case of frequent recurrences of HenochSchönlein purpura was reported when the contraceptive was discontinued and the authors suggested that inflammatory activity might be modulated by sex steroids. ${ }^{3}$ These three cases including our present case may be examples of endocrinal modulation of vasculitis. Vasculitis, in general, affects the elderly, also indicating hormonal involvement. This observation may be a clue to clarifying the pathogenesis and endocrinal modulation of vasculitis.

Because aromatase inhibitors are commonly used drugs, and vasculitis can be severe, clinicians should be aware of their association.

\section{Authors' affiliations}

H Shoda, S Inokuma, N Yajima, Y Tanaka, K Setoguchi, Department of Allergy and Immunological Diseases, Tokyo Metropolitan Komagome Hospital, Tokyo, Japan

Correspondence to: Dr H Shoda, shoda-tky@umin.ac.jp

Accepted 25 August 2004

\section{REFERENCES}

1 Goss PE, Tye LM. Anastrozole: a new selective nonsteroidal aromatase inhibitor. Oncology 1997;11:1697-703.

2 Drago F, Arditi M, Rebora A. Tamoxifen and purpuric vasculitis. Ann Intern Med 1990;112:965-6.

3 Merrill J, Lahita RG. Henoch-Schönlein purpura remitting in pregnancy and during sex steroid therapy. Br J Rheumatol 1994;33:586-8. 


\section{$\beta$ Thalassaemic trait and systemic lupus erythematosus G Castellino, M Govoni, M Padovan, N Rizzo, F Trotta}

A naemia of varying degree is a quite common finding in systemic lupus erythematosus (SLE), but only rarely has an association with concomitant haemoglobinopathies and, in particular, $\beta$ thalassaemia minor, been studied.

In Ferrara and Rovigo areas (the Po' delta, in the north east of Italy) the prevalence of $\beta$ thalassaemia is higher than in other parts of Italy $(13.1 \% \vee 2.1 \%)$. We have previously studied the prevalence of this haemoglobinopathy in patients with rheumatoid arthritis (RA) ${ }^{1}$ and, subsequently, in patients with SLE from this area. ${ }^{2}$ We found that patients with RA have a higher prevalence and patients with SLE have a lower prevalence of $\beta$ thalassaemia than a control group (19.8\% and $9.8 \% \vee 13.1 \%$, respectively ).

In this study we describe the clinical characteristics and laboratory findings of our patients with SLE with $\beta$ thalassaemia and compare them with those of patients with SLE without $\beta$ thalassaemia.

\section{PATIENTS, METHODS, AND RESULTS}

Among 177 consecutive patients with SLE (145 female, 32 male, mean age 54 years, range 20-89) born in the Ferrara and Rovigo areas and attending our institution between January 1998 and June 2003 we found 17 subjects with $\beta$ thalassaemia (all female, mean age 53 years, range 20-88). Clinical and serological characteristics of these subjects were compared with those of 70 patients with SLE without $\beta$ thalassaemia matched for sex, age, and disease duration coming from the same area.

Tables 1 and 2 show the demographic and clinical findings for patients with SLE with and without $\beta$ thalassaemia.

The most remarkable findings were a greater prevalence in $\beta$ thalassaemia patients of an associated Sjögren's syndrome (SS) $(71 \% \vee 16 \%, \mathrm{p}<0.0001)$ and a greater prevalence of central nervous system involvement $(59 \%$ v $21 \%, \mathrm{p}<0.005)$, serositis $(47 \% v 17 \%, \mathrm{p}<0.05)$, and renal disease $(18 \% v 4 \%$, NS). The laboratory data showed a greater prevalence of extractable nuclear antigen SSA antibodies in patients with $\beta$ thalassaemia $(71 \% \quad v 23 \%, \mathrm{p}<0.0001)$ and persistently reduced (at least three consecutive determinations) C3 and/ or C4 complement fractions (59\% v 27\%, $\mathrm{p}<0.05)$.

Table 1 Demographic data of patients with SLE with and without $\beta$ thalassaemia

\begin{tabular}{|c|c|c|}
\hline & \multicolumn{2}{|l|}{ Patients with SLE } \\
\hline & $\begin{array}{l}\text { With } \\
\beta \text { thalassaemia } \\
(n=17)\end{array}$ & $\begin{array}{l}\text { Without } \\
\beta \text { thalassaemia } \\
(n=70)\end{array}$ \\
\hline $\operatorname{Sex}(M / F)$ & $0 / 17$ & $0 / 70$ \\
\hline Age (years), mean (range) & $53.4(20-88)$ & $52.8(20-81)$ \\
\hline Disease duration (years), mean (range) & $9.5(2-30)$ & $9.2(2-24)$ \\
\hline
\end{tabular}

Table 2 Clinical manifestations in patients with SLE with and without $\beta$ thalassaemia

\begin{tabular}{llll}
\hline & \multicolumn{2}{l}{ Patients with SLE } & \\
\cline { 2 - 3 } & $\begin{array}{l}\text { With } \\
\boldsymbol{\beta} \text { thalassaemia } \\
\text { No }(\%)\end{array}$ & $\begin{array}{l}\text { Without } \\
\boldsymbol{\beta} \text { thalassaemia } \\
\text { No }(\%)\end{array}$ & p Value \\
\hline Siögren's syndrome & $12(71)$ & $11(16)$ & $<0.0001$ \\
CNS & $10(59)$ & $15(21)$ & $<0.005$ \\
Nephropathy & $3(18)$ & $3(4)$ & NS \\
Thrombosis & $3(18)$ & $10(14)$ & NS \\
Haematological & $3(18)$ & $24(34)$ & NS \\
Serositis & $8(47)$ & $12(17)$ & $<0.05$ \\
Osteoporosis & $7(41)$ & $23(33)$ & NS \\
Dyslipidosis & $4(24)$ & $20(29)$ & NS \\
\hline
\end{tabular}

\section{DISCUSSION}

The association between SLE and haemoglobinopathies has been poorly explored to date.

Sixteen cases have been reported describing the coexistence of sickle cell disease ${ }^{3}$ and SLE, but only Kaloterakis et al reported a case of sickle cell/ $\beta^{\prime \prime}$ thalassaemia in a patient with SLE. ${ }^{4}$

In this study we found a greater prevalence of an associated SS in patients with SLE and $\beta$ thalassaemia than in those patients with SLE without $\beta$ thalassaemia. The same finding has already been reported by Montecucco et al in patients with RA with $\beta$ thalassaemia. ${ }^{5}$ Reasons for this association are at present unknown. Further studies of patients with different connective tissue disorders should be performed to exclude the possibility that the association is fortuitous.

In addition to SS, all major systemic complications were more prevalent in $\beta$ thalassaemia patients with SLE. It is unclear whether the increased presence of SSA antibodies among those with $\beta$ thalassaemia may have some role ${ }^{6}$ or whether a more severe disease with persistently reduced C3 and C4 levels is typical of patients with $\beta$ thalassaemia. Both an increased incidence of atherosclerotic events ( secondary to the chronic hypercoagulable state ${ }^{7}$ or to the homocistinaemia $^{89}$ ) and a reduced ability to bind immune complexes ${ }^{10}$ have been described in $\beta$ thalassaemia subjects and might be responsible for a more aggressive disease in these subjects.

In conclusion, in contrast with other systemic rheumatic diseases (RA, in particular), the prevalence of $\beta$ thalassaemia in patients with SLE seems to be lower than in the general population. However, when the two conditions coexist, SLE seems to have a more severe course and to be more frequently associated with SS.

\section{Authors' affiliations}

G Castellino, M Govoni, M Padovan, N Rizzo, F Trotta, Rheumatology Unit, Department of Clinical and Experimental Medicine, University of Ferrara, Italy 
Correspondence to: $\operatorname{Dr} G$ Castellino, Sezione di Reumatologia, Dipartimento di Medicina Clinica e Sperimentale, Università degli Studi di Ferrara, Corso Giovecca 203, 44100 Ferrara; gabriella_castellino@ yahoo.it; trf@unife.it

Accepted 18 September 2004

\section{REFERENCES}

1 Marcolongo R, Trotta F, Scaramelli M. Beta-thalssaemic trait and rheumatoid arthritis. Lancet 1975;i:1141.

2 Castellino G, Govoni M, Trotta F. Beta-thalassemic trait and systemic lupus erythematosus. Clin Exp Rheumatol 2004;22:382-3.

3 Saxena VR, Mina R, Moallem HJ, Rao SP, Miller ST. Systemic lupus erythematosus in children with sickle cell disease. J Pediatr Hematol Oncol 2003;25:668-71.
4 Kaloterakis A, Filiotou A, Haziyannis S. Sickle cell/ $\beta$ "-Thalassemia and systemic lupus erythematosus. Lupus 1999;8:778-81.

5 Montecucco C, Caporali R, Rossi S, Epis O. Rheumatoid arthritis in betathalassaemia trait. BrJ Rheumatol 1999;38:1021-2.

6 St Clair EW. Anti-La antibodies. Rheum Dis Clin North Am 1992;18:359-76.

7 Kyriakou DS, Alexandrakis MG, Kyriakou ES, Liapi D, Kourelis TV, Passam F, et al. Activated peripheral blood and endothelial cells in thalassemic patients. Ann Hematol 2001;80:577-83.

8 Advani R, Sorenson S, Shinar E, Lande W, Rachmilewitz E, Schrier SL. Characterization and comparison of the red blood cell membrane damage in severe human $\alpha$ and $\beta$ thalassemia. Blood 1992;74:2194.

9 Schrier SL. Thalassemia: pathophysiology of red cell changes. Annu Rev Med 1994:45:211.

10 Giuliani AL, Bolzonella C, Aloni A, Confalonieri G, Moretti C, Lutz H, et al. RBC-CR1 expression, immune complex binding and reticulocytes in blood from feti, elderly and anemic adults [abstract]. Biogerontology 2002;3(suppl 1):abstr, 1389

\section{Feasibility of 1 hour infliximab infusions}

\section{R F van Vollenhoven, E Gullström, L Klareskog}

$\mathrm{S}$ ince 1 January 2003 we have changed our routine clinical practice and now give infliximab over 1 instead of 2 hours to those patients who have had at least three uneventful prior infusions (that is, did not experience infusion related side effects). To date, we have given 440 such infusions to 113 patients. Four infusions (0.9\%) occurring in four different patients were associated with an adverse event: general infusion related symptoms rated as mild in two patients, tiredness rated as moderate after the infusion in one patient, and a sense of pressure over the eyes in one patient with prior open angle glaucoma. This last patient was subsequently examined by an ophthalmologist and ocular pressure was documented as normal. The pressure sensation resolved subsequently. The $<1 \%$ incidence of infusion related adverse events compares favourably with the overall incidence of such events at our institution, which is about 5\%; this is of course explained by our selection of patients with prior uneventful infusions.

We conclude that more rapid infliximab infusions over 1 hour, when given to patients who have tolerated at least three previous infliximab infusions without side effects, are tolerated well. Administering infliximab over 1 hour to such patients is a useful saving of time for both the patient and the healthcare provider.

\section{Authors' affiliations \\ R F van Vollenhoven, E Gullström, L Klareskog, Department of Rheumatology, D2-1 Karolinska Hospital, Stockholm, Sweden}

Correspondence to: Associate Professor R F van Vollenhoven, ronald. vanvollenhoven@ks.se

Accepted 21 October 2003 